\title{
KAJIAN BUDIDAYA Daphnia magna MENGGUNAKAN AIR REBUSAN KEDELAI DAN AIR CUCIAN BERAS
}

\author{
STUDY OF Daphnia magna CULTIVATION USING SOY BOILED WATER AND RICE \\ WASHING WATER
}

\author{
Hernika Simanjuntak ${ }^{1,2}$, Ernik Yuliana ${ }^{2 *}$, Sinar Pagi Sektiana ${ }^{1}$ \\ ${ }^{1}$ Politeknik Ahli Usaha Perikanan (AUP) Serang, Banten \\ ${ }_{2}^{2}$ Program Studi Magister Manajamen Perikanan, Program Pascasarjana, Universitas Terbuka
}

Teregistrasi I tanggal: 01 November 2020; Diterima setelah perbaikan tanggal: 16 Januari 2021; Disetujui terbit tanggal: 26 Januari 2021

\begin{abstract}
ABSTRAK
Daphnia magna memiliki banyak keunggulan sebagai pakan alami pada budidaya ikan fase larva. Tujuan penelitian ini adalah membandingkan pertumbuhan Daphnia magna pada budidaya dengan menggunakan beberapa sumber air pupuk/pakan. Penelitian ini dilakukan secara eksperimental dengan metode Rancangan Acak Lengkap (RAL) dengan perlakuan yaitu pemberian pupuk pakan: kotoran ayam, air cucian beras, dan air rebusan kedelai, masing-masing pada konsentrasi $2 \%, 5 \%$ dan $10 \%$ dengan 3 kali pengulangan. Analisis data yang digunakan adalah uji statistik ANOVA dan dilanjutkan dengan uji beda nyata terkecil (BNT). Hasil penelitian menunjukkan bahwa pertumbuhan populasi yang lebih baik adalah dengan penambahan pakan/pupuk air rebusan kedelai dengan konsentrasi berturut-turut $10 \%, 5 \%$, dan $2 \%$. Hasil uji ANOVA menunjukkan perbedaan yang siginifikan antar perlakuan, namun tidak berbeda signifikan pada penggunaan konsentrasi yang berbeda. Hasil uji BNT menunjukkan bahwa air rebusan kedelai konsentrasi 5\% dan $10 \%$ memberikan respon yang lebih baik dengan rata-rata pertumbuhan populasi 346 ekor dan 534 ekor. Hasil pengujian kandungan protein dan lemak didapatkan hasil bahwa air rebusan kedelai lebih tinggi dibanding yang lainnya yaitu rata-rata sebesar $2,50 \%$ dan $5,77 \%$. Pengujian kandungan Escherichia coli didapatkan hasil jika semua perlakuan menunjukkan kandungan E. coli yang negatif.
\end{abstract}

Kata kunci: Daphnia magna, kandungan nutrisi, pertumbuhan populasi

\begin{abstract}
Daphnia magna has many advantages as natural food in larval stage fish culture. This study aims to compare the growth of Daphnia magna in cultivation using several sources of fertilizer/feed water. This research was conducted experimentally with a completely randomized design method with the treatment of feeding fertilizer: chicken manure, rice washing water, and soy boiled water, each at a concentration of 2\%, 5\% and 10\% with 3 repetitions. The data analysis used was the ANOVA statistical test and continued with the least significant difference test (LSD). The results indicated that the better population growth was the addition of soybean boiled feed/water fertilizer with concentrations of $10 \%, 5 \%$, and $2 \%$, respectively. The results of the ANOVA test indicated that was a significant difference between treatments, but not significantly different at the use of different concentrations. LSD test results indicated that soybean boiled water with a concentration of 5\% and 10\% gave a better response with an average population growth of 346 and 534 individuals.
\end{abstract}

\footnotetext{
Korespondensi Penulis:

*Emailernik@ecampus.ut.ac.id

DOI: http://dx.doi.org/10.15578/plgc.v2i1.9412
} 
The results of testing the protein and fat content showed that the cooking water for soybeans was higher than the others, namely $2.50 \%$ and $5.77 \%$, respectively. The test for Escherichia coli content was obtained if all treatments showed negative E. coli content.

\section{Keywords: Daphnia magna, nutritional content, population growth}

\section{PENDAHULUAN}

Ketersediaan pakan alami sangat dibutuhkan untuk perkembangan ikan khususnya stadia larva pada budidaya ikan air tawar. Ikan pada stadia larva membutuhkan protein yang lebih tinggi dibandingkan ikan dewasa, dan tingkat protein optimum dalam pakan untuk pertumbuhan ikan berkisar 25-50\% (Maulidiyanti et al., 2015). Pakan alami yang digunakan harus memiliki beberapa syarat untuk memenuhi kebutuhan budidaya antara lain memiliki kandungan nutrisi yang tinggi, tidak mencemari lingkungan, dan mudah untuk dibudidaya secara massal. Daphnia magna merupakan salah satu pakan alami jenis zooplankton (filum Arthropoda dan subfilum Crustacea) yang dapat memenuhi persyaratan sebagai pakan alami yang baik (Pangkey, 2009). Daphnia magna banyak digunakan sebagai pakan alami bagi larva ikan karena memiliki kandungan nutrisi yang tinggi, yaitu protein $4 \%$, lemak $0,54 \%$, karbohidrat $0,67 \%$ dan abu $0,15 \%$ (Haryati, 2005). Kandungan nutrisi tersebut khususnya protein dan lemak pada Daphnia magna masih dapat ditingkatkan (Haryati, 2005) dengan melakukan rekayasa pada budidayanya. Mengingat sifatnya sebagai filter feeder non-selective (Pennak, 1989) sehingga memungkinkan untuk dilakukan budidaya dengan suspensi partikel dan bakteri yang melimpah. Media yang dapat digunakan untuk pengayaan nutrisi pada budidaya dapat dilakukan dengan menggunakan air rebusan kedelai dan air cucian beras.

Pemanfaatan air rebusan kedelai dan air cucian beras pada budidaya Daphnia magna diduga dapat meningkatkan kandungan nutrisi khususnya protein dan lemak serta jumlah individunya. Penggunaan air rebusan kedelai dan air cucian beras ini dapat menjadi alternatif dalam upaya budidaya Daphnia magna mengingat selama ini masih banyak budidaya yang dilakukan dengan menggunakan pupuk kotoran ayam. Penggunaan pupuk kotoran ayam bertujuan untuk merangsang pertumbuhan fitoplankton dan zooplankton. Namun seiring dengan perkembangan industri perikanan dan belum adanya kontrol kualitas keamanan pangan muncul isu yang berkaitan dengan kualitas dan keamanan produk perikanan dalam kegiatan budidaya. Permasalahan lain yang ditimbulkan dari penggunaan kotoran ayam (manure) adalah penggunaan antibiotic growth promotor (AGP) pada pakan ayam yang dapat mempengaruhi kualitas dan keamanan produk perikanan yang dihasilkan (Yanuartono et al., 2018). Pupuk kotoran ayam juga menimbulkan laju kematian Daphnia magna tertinggi kedua setelah kotoran kambing dengan laju 0,206 (Akbar et al., 2017). Penggunaan pupuk kotoran ayam juga dikhawatirkan mengandung bakteri Escherichia coli.

Pemanfaatan air rebusan kedelai dan air cucian beras diharapkan dapat mengurangi keberadaan limbah air rebusan kedelai dalam proses pembuatan tempe dan limbah rumah tangga sebagai hasil pencucian beras. Tujuan penelitian adalah menganalisis perbaikan pengelolaan budidaya, peningkatan produksi, jumlah populasi, kandungan nutrisi, kandungan E. coli, dan perbaikan budidaya Daphnia magna dengan menggunakan air rebusan kedelai dan air cucian beras. 


\section{BAHAN DAN METODE}

Penelitian dilaksanakan pada bulan Maret-Mei 2020, bertempat di Laboratorium Biologi Politeknik Ahli Usaha Perikanan (AUP) Kampus Serang, Banten. Alat yang digunakan adalah toples kaca volume 3 liter, blower, $\mathrm{pH}$ indicator, dissolved oxygen (DO) kit, thermometer, aerator, scoop net, petridisk, dan alat tulis. Bahan yang digunakan pada penelitian ini adalah Daphnia magna sebanyak 1.080 ekor, air rebusan kedelai, air cucian beras, dan kotoran ayam.

Penelitian ini dilakukan secara eksperimental dengan pemberian air rebusan kedelai dengan konsentrasi $2 \%$, $5 \%$ dan $10 \%$ dan pemberian air cucian beras dengan konsentrasi 2\%, 5\% dan $10 \%$ masing-masing perlakuan dilakukan tiga kali ulangan. Daphnia magna yang digunakan diletakkan pada masingmasing toples kaca dengan jumlah tebar 40 ekor/toples, kemudian diberi perlakuan sesuai dengan konsentrasi yang ditentukan. Pengamatan pertumbuhan populasi dilakukan pada awal dan akhir penelitian.

Parameter yang diamati pada penelitian ini adalah pertumbuhan populasi, kandungan protein dan kandungan lemak, kandungan bakteri E. coli, kualitas air yang meliputi suhu, $\mathrm{pH}$, dan DO. Data penelitian pertumbuhan populasi di analisis secara statistik dengan menggunakan uji ANOVA dan uji beda nyata terkecil (BNT) untuk mengetahui pengaruh dan perbedaan pemberian air rebusan kedelai dan air cucian beras dengan masingmasing konsentrasi yang berbeda antar perlakuan. Kandungan protein dan lemak serta kandungan bakteri E. coli dilakukan pengujian pada laboratorium Unit Pelaksana Teknis Daerah (UPTD) Pengujian dan Penerapan Mutu Hasil Perikanan Dinas Kelautan dan Perikanan Pemerintah Provinsi Banten.

\section{HASIL DAN BAHASAN HASIL}

Hasil penelitian $\begin{array}{r}\text { berupa } \\ \text { pertumbuhan populasi, kandungan }\end{array}$
protein dan lemak, kualitas air dan
kandungan E. coli pada Daphnia magna
dengan pemberian air rebusan kedelai dan
air cucian beras dengan konsentrasi yang
telah ditentukan disajikan pada Tabel 1
dan Gambar 1. Rata-rata pertumbuhan
populasi Daphnia magna pada masing-
masing perlakuan disajikan pada
Gambar 2.

Tabel 1. Hasil Pertumbuhan Populasi Daphnia magna

Table 1. Results of Population Growth of Daphnia magna

\begin{tabular}{ccccc}
\hline \multirow{2}{*}{ Perlakuan } & \multicolumn{3}{c}{ Jumlah Individu dalam Ulangan } & \multicolumn{1}{c}{$\begin{array}{c}\text { Rerata } \\
\text { BNT 5\%=107,15 }\end{array}$} \\
\cline { 2 - 4 } A1 & $\mathbf{1}$ & $\mathbf{2}$ & $\mathbf{3}$ & $8^{\mathrm{a}}$ \\
A2 & 9 & 15 & 0 & $7^{\mathrm{a}}$ \\
A3 & 21 & 0 & 0 & $10,66^{\mathrm{a}}$ \\
B1 & 0 & 0 & 32 & $40,66^{\mathrm{a}}$ \\
B2 & 40 & 50 & 32 & $170^{\mathrm{b}}$ \\
B3 & 0 & 162 & 123 & $118,66^{\mathrm{b}}$ \\
C1 & 72 & 202 & 338 & $128,33^{\mathrm{b}}$ \\
C2 & 103 & 179 & 112 & $346,66^{\mathrm{c}}$ \\
C3 & 298 & 387 & 355 & $534,66^{\mathrm{c}}$ \\
\hline
\end{tabular}

Keterangan: A1 = perlakuan dengan kotoran ayam 2\%; A2 = perlakuan kotoran ayam 5\%; A3 = perlakuan kotoran ayam 10\%; B1 = perlakuan air cucian beras 2\%; B2 = perlakuan air cucian beras 5\%; B3 = perlakuan air cucian beras $10 \% ; \mathrm{C} 1=$ perlakuan air rebusan kedelai $2 \% ; \mathrm{C} 2=$ perlakuan air rebusan kedelai $5 \%$; $\mathrm{C} 3=$ perlakuan air rebusan kedelai $10 \%$ 
Kajian Budidaya Daphnia magna ........ Air Cucian Beras (Simanjuntak H, et al)

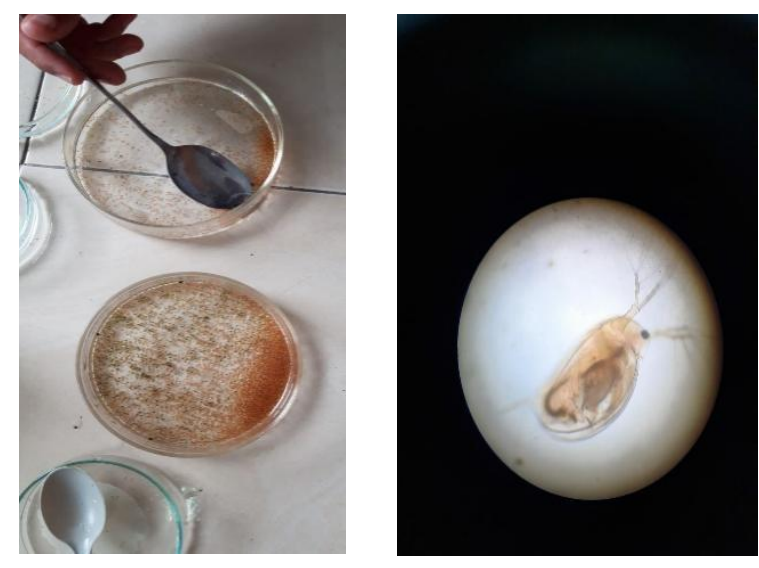

Gambar 1. Penghitungan dan penampakan Daphnia magna di bawah mikroskop

Figure 1. Counting and appearance of Daphnia magna under microscope

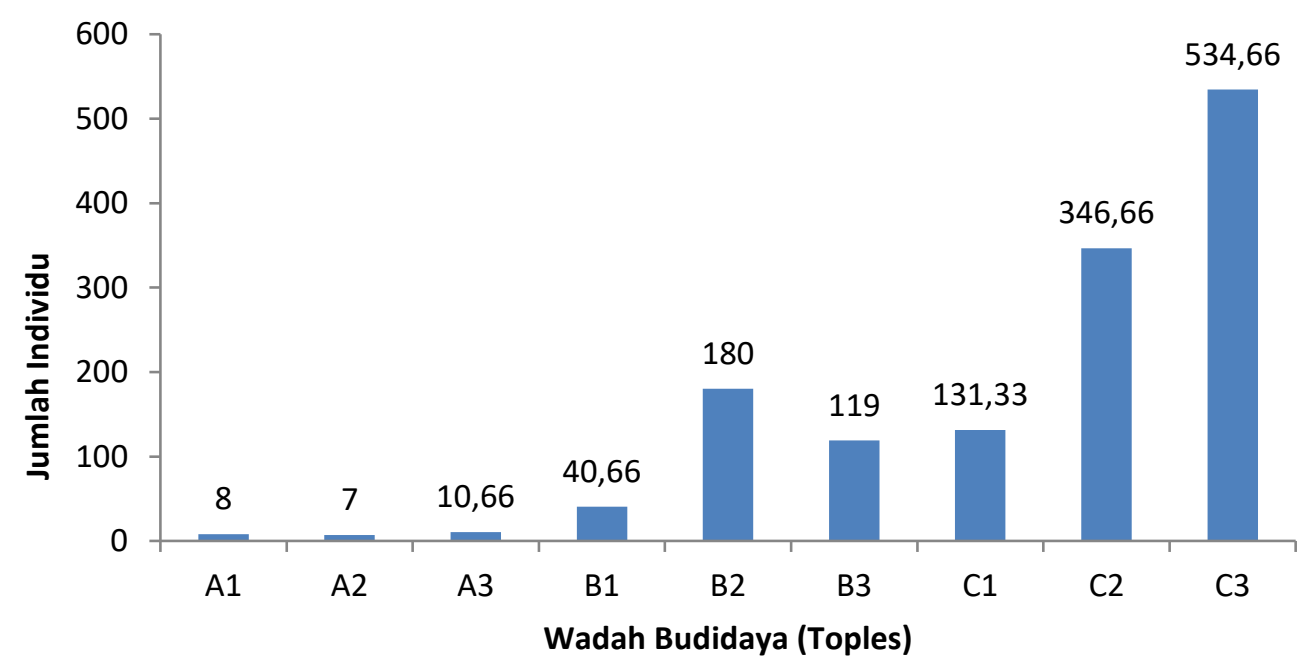

Gambar 2. Rata-rata pertumbuhan populasi Daphnia magna

Figure 2. Average of Daphnia magna growth population

Tabel 2 menyajikan hasil pengujian kandungan protein dan lemak pada Daphnia magna dengan penambahan pakan/pupuk air rebusan kedelai, air cucian beras dan kotoran ayam dengan masing-masing konsentrasi yang telah ditentukan.

Tabel 2. Hasil Pengujian Kandungan Protein dan Lemak pada Budidaya Daphnia magna Table 2. Result of Testing Protein and Fat Levels on Daphnia magna cultivation

\begin{tabular}{ccccccc}
\hline \multirow{2}{*}{ Perlakuan } & \multicolumn{3}{c}{ Kandungan Protein (\%) } & \multicolumn{3}{c}{ Kandungan Lemak (\%) } \\
\cline { 2 - 7 } & $\mathbf{2 \%}$ & $\mathbf{5 \%}$ & $\mathbf{1 0 \%}$ & $\mathbf{2 \%}$ & $\mathbf{5 \%}$ & $\mathbf{1 0 \%}$ \\
\hline A & 2,28 & 2,06 & 2,32 & 3,36 & 3,14 & 3,75 \\
B & 2,59 & 2,23 & 2,58 & 0,61 & 0,68 & 0,78 \\
C & 2,58 & 2,36 & 2,58 & 5,76 & 5,72 & 5,83 \\
\hline
\end{tabular}

Keterangan: A = perlakuan dengan kotoran ayam; B = Perlakuan dengan air cucian beras; $\mathrm{C}=$ perlakuan dengan air rebusan kedelai 
Tabel 3 menyajikan kisaran ratarata pengukuran kualitas air pengelolaan budidaya Daphnia magna dengan lama pemeliharaan 10 hari. Sedangkan, Tabel 4 menyajikan hasil pengujian bakteri E. coli pada budidaya Daphnia magna dengan pemberian pakan/pupuk air rebusan kedelai, air cucian beras, dan kotoran ayam dengan masing konsentrasi yang telah ditentukan.

Tabel 3. Kisaran Rata-rata Pengukuran Kualitas Air pada Budidaya Daphnia magna

Table 3. Range of Average Water Quality Measurements of Daphnia magna cultivation

\begin{tabular}{cccc}
\hline \multirow{2}{*}{ Perlakuan } & \multicolumn{3}{c}{ Parameter } \\
\cline { 2 - 4 } & Suhu ( $\left.{ }^{\mathbf{0}} \mathbf{C}\right)$ & $\mathbf{p H}$ & DO (mg/l) \\
\hline A & 25 & 8 & 6 \\
B & 25 & 8 & $5-6$ \\
C & 25 & 8 & $4-6$ \\
\hline
\end{tabular}

Keterangan: $\mathrm{A}=$ perlakuan dengan kotoran ayam; $\mathrm{B}=$ Perlakuan dengan air cucian beras; $\mathrm{C}=$ perlakuan dengan air rebusan kedelai

Tabel. 4 Hasil Pengujian Bakteri E. coli pada Pengelolaan Daphnia magna

Table 4. E. coli Bacteria Test Results on the Management of Daphnia magna

\begin{tabular}{cccc}
\hline \multirow{2}{*}{ Perlakuan } & \multicolumn{3}{c}{ Kandungan $\boldsymbol{E}$. coli $(\mathrm{MPN} / \mathrm{g})$} \\
\cline { 2 - 4 } & $\mathbf{2 \%}$ & $\mathbf{5 \%}$ & $\mathbf{1 0 \%}$ \\
\hline $\mathrm{A}$ & $<3$ & $<3$ & $<3$ \\
$\mathrm{~B}$ & $<3$ & $<3$ & $<3$ \\
$\mathrm{C}$ & $<3$ & $<3$ & $<3$ \\
\hline
\end{tabular}

Keterangan: $\mathrm{A}=$ perlakuan dengan kotoran ayam; $\mathrm{B}=$ Perlakuan dengan air cucian beras; $\mathrm{C}=$ perlakuan dengan air rebusan kedelai

\section{BAHASAN}

Hasil pertumbuhan populasi selama pemeliharaan (Tabel 1) dapat dilihat jika rata-rata pertumbuhan populasi Daphnia magna dengan menggunakan air rebusan kedelai dengan konsentrasi $10 \%$ yaitu 534 ekor. Pertumbuhan populasi tertinggi kedua dan ketiga berturut-turut adalah perlakuan air rebusan kedelai dengan konsentrasi $5 \%$ dan 2\%, yaitu masingmasing 346 ekor dan 131 ekor. Pada Gambar 2 juga dapat dilihat bahwa hasil rata-rata terendah pertumbuhan populasi Daphnia magna terjadi pada perlakuan dengan kotoran ayam, yaitu hasil rata-rata selama penelitian adalah 7 ekor pada konsentrasi 5\%. Hal tersebut disebabkan komposisi dari kedelai yang sebagian besar terdiri atas protein, karbohidrat, dan lemak, maka dalam air rebusan kedelai juga terkandung komposisi tersebut
(Wulan, 2014). Semakin tinggi konsentrasi yang digunakan maka semakin tinggi pula kandungan protein dan lemaknya.

Pada penelitian ini jumlah pakan per hari dibagi untuk pakan 10 hari pemeliharaan. Hal ini dilakukan untuk mengurangi kepekatan pada media pemeliharaan. Media pemeliharaan yang pekat menyebabkan banyaknya gelembung atau busa pada toples kaca hal ini menyebabkan banyaknya Daphnia magna menempel pada dinding toples kaca dan mati.

Komposisi protein dan lemak pada air rebusan kedelai dimanfaatkan mikroorganisme untuk mengurai senyawa organik yang ada pada air rebusan kedelai. Karena air rebusan kedelai termasuk ke dalam bahan biodegradable yaitu bahan buangan yang dapat dihancurkan oleh mikroorganisme 
(Mahida, 1986). Mikroorganisme yang ada berfungsi sebgai pakan bagi Daphnia magna. Mengingat sifat dari Daphnia magna adalah non selective filter feeder yaitu memakan partikel tersuspensi yang sesuai dengan bukaan mulutnya, maka tidak hanya mikroorganisme yang sesuai bukaan mulut Daphnia magna saja yang menjadi pakan tetapi bahan yang tersuspensi pada air rebusan kedelai pun menjadi pakan (Pangkey, 2009). Oleh karena itu, jumlah pakan yang tersedia selama proses pemeliharaan skala laboratorium ini Daphnia magna lebih berlimpah dibandingkan dengan penggunaan pakan/pupuk lain yang digunakan. Hal ini yang menjadikan pertumbuhan populasi pada air rebusan kedelai lebih unggul dibanding dengan pertumbuhan populasi pada air cucian beras dan kotoran ayam.

Namun, pertumbuhan populasi pada aplikasi konsentrasi masing-masing jenis pupuk/pakan berbanding terbalik dengan pertumbuhan populasi dengan pengaplikasian jenis pupuk/pakan yang berbeda. Hal ini terlihat pada uji statistik ANOVA dari pertumbuhan populasi dengan penggunaan konsentrasi yang berbeda pada masing-masing jenis pupuk/pakan yang digunakan menunjukkan bahwa jumlah populasi tidak berbeda nyata antara konsentrasi $2 \%$, 5\%, dan 10\%. Dapat dilihat jika jumlah populasi pada konsentrasi yang berbeda tidak berbeda jauh satu sama lain pada jenis pupuk/pakan yang sama, hal ini disebabkan karena rentang konsentrasi yang dilakukan penulis terlalu pendek. Untuk melihat pengaruh konsentrasi pada pertumbuhan populasi Daphnia magna maka perlu dilakukan penelitian lebih lanjut dengan rentang konsentrasi yang lebih jauh.

Hasil pengujian kandungan nutrisi yaitu pengujian kandungan protein mengikuti acuan uji SNI 01-2354.4-2006 dan kandungan lemak dengan acuan uji SNI 2354-3-2017. Hasil pengukuran kandungan protein (Tabel menunjukkan bahwa hasil pemberian pupuk/pakan air rebusan kedelai sedikit lebih tinggi dibanding dengan air cucian beras. Hal ini dilihat dari hasil uji laboratorium yang mempunyai rata-rata kandungan protein pada air rebusan kedelai 2,50\%, air cucian beras 2,46\% dan kotoran ayam 2,22\%. Nilai kandungan protein pada penelitian skala laboratorium ini lebih rendah dibandingkan nilai protein Haryati (2005) yaitu 4\%. Tingginya kandungan protein pada Daphnia magna dipengaruhi nutrien yang terkandung dalam media kultur dimana semakin tinggi kandungan nitrat dan fosfat maka semakin tinggi kandungan proteinnya dan semakin rendah kandungan lipidnya (Herawati \& Agus, 2013). Nilai protein yang rendah pada rebusan kedelai disebabkan oleh pakan per hari dibagi ke dalam 10 hari pemberian pakan, hal inilah yang menyebabkan nilai protein pada Daphnia magna dengan penambahan air rebusan kedelai rendah. Pakan per hari yang dibagi ke dalam 10 hari pemberian pakan dilakukan untuk mengurangi gelembung atau busa pada toples kaca yang menyebabkan banyaknya Daphnia magna yang menempel dan mati.

Kandungan lemak pada pemberian pupuk/pakan air rebusan kedelai lebih tinggi dibanding dengan air cucian beras. Hal ini dilihat dari hasil uji laboratorium, dimana rata-rata kandungan lemak pada air rebusan kedelai $5,77 \%$, sedangkan kandungan lemak air cucian beras dan kotoran ayam menunjukkan hasil dengan rata-rata $0,69 \%$ dan 3,41\%. Hasil penelitian ini menunjukkan perbedaan signifikan antar perlakuan dengan konsentrasi yang berbeda, nilai kandungan lemak pada perlakuan air rebusan kedelai lebih tinggi dibandingkan dengan nilai kandungan lemak hasi penelitian Haryati (2005), yaitu 0,54\%. Kandungan lemak pada perlakuan air rebusan kedelai lebih tinggi dibandingkan dengan perlakuan lain dikarenakan air rebusan kedelai mengandung bakteri 
Lactobacillus sp. Menurut Jamila \& Tangdilintin (2011), Lactobacillus sp. menguraikan karbohidrat dan menghasilkan asam-asam lemak sehingga kandungan lemak pada perlakuan air rebusan kedelai meningkat. Kandungan lemak pada Daphnia magna ini dapat lebih tinggi jika saja pakan tidak dibagi ke dalam 10 hari pemberian pakan.

Kualitas air pada budidaya Daphnia magna dengan menggunakan air rebusan kedelai dan air cucian beras selama penelitian skala laboratorium pada masing-masing perlakuan adalah: suhu $25^{\circ} \mathrm{C}$, oksigen terlarut $4-6 \mathrm{mg} / \mathrm{L}$, dan $\mathrm{pH}$ 8. Suhu selama penelitian pada skala laboratorium sesuai dengan suhu lingkungan Daphnia magna untuk dapat tumbuh dan berkembang biak yaitu 24$28^{0} \mathrm{C}$ (Darmawan, 2014). Suhu selama penelitian skala laboratorium dapat dikatakan stabil dan sesuai karena pada ruang penelitian pada laboratorium biologi terdapat air conditioner (AC) sehingga menyebabkan suhu pada ruangan tersebut tetap stabil. Begitu juga oksigen terlarut (DO) selama penelitian skala laboratorium sesuai untuk lingkungan budidaya Daphnia magna, yaitu oksigen terlarut optimal yaitu $>3$ $\mathrm{mg} / \mathrm{L}$ (Mubarak et al., 2009). Oksigen terlarut (DO) selama penelitian skala laboratorium adalah stabil, disebabkan oleh penggunaan aerasi selama penelitian. Nilai $\mathrm{pH}$ selama penelitian pada skala laboratorium termasuk ke dalam katagori baik untuk pemeliharaan dan perkembang biakan Daphnia magna, yaitu 6,5-9 atau 7-8,6 (Rahayu et al., 2012). Hasil pengujian bakteri E. coli yang disajikan pada Tabel 4, menunjukkan bahwa kandungan bakteri E. coli pada Daphnia magna penelitian skala laboratorium pada masing-masing perlakuan menunjukkan hasil negatif.

\section{SIMPULAN}

Budidaya Daphnia magna dengan menggunakan air rebusan kedelai dan air cucian beras memberikan respon yang baik. Hasil paling baik adalah budidaya dengan penggunaan air rebusan kedelai. Peningkatan produksi Daphnia magna dari segi pertumbuhan populasi, kandungan protein, dan kandungan lemak penggunaan air rebusan kedelai memberikan respon yang lebih baik dibandingkan dengan penggunaan air cucian beras dengan rata-rata pertumbuhan adalah 534 individu, kandungan protein $2,50 \%$ dan kandungan lemak 5,77. Tidak terdapat kontaminasi bakteri merugikan pada setiap perlakuan yang ditandai dengan kandungan E. coli negatif. Kualitas air pada budidaya Daphnia magna dengan menggunakan air rebusan kedelai dan air cucian beras berada pada kisaran yang baik untuk pertumbuhan Daphnia magna.

\section{DAFTAR PUSTAKA}

Akbar, M.G.N., Hamdani, H., \& Buwono, I.D. (2017). Pengaruh perbedaan pupuk organik terhadap laju kematian populasi Daphnia sp. Jurnal Perikanan dan Kelautan, 8 (2), 176-182.

Darmawan, J. (2014). Pertumbuhan Populasi Daphnia sp.pada Media Budidaya dengan Penambahan Air Buangan Budidaya Ikan Lele Dumbo (Clarias Gariepinus Burchell,1982). Balai Penelitian Pemuliaan Ikan, Sukamandi. Hlm. 57-63.

Haryati. (2005). Pengaruh Penggantian Artemia Salina dengan Daphnia sp Terhadap Pertumbuhan dan Kelangsungan Hidup Benih Gurami (Osphronemus gouramy L). Tesis. Institut Pertanian Bogor. Bogor

Herawati, V.E., \& Agus, M. (2013). Analisis Pertumbuhan dan Kelulushidupan Larva Lele (Clarias gariepenus) yang diberi Pakan Daphnia sp. Hasil Kultur Massal Menggunakan Pupuk 
Organik difermentasi. Universitas Diponegoro, Semarang.

Jamila, \& Tangdilintin, F.K. (2011). Kandungan Lemak Kasar, BETN, Kalsium dan Phospor Feses Ayam yang Difermentasi Bakteri Actobacillus sp. Seminar Nasional. Teknologi Perternakan dan Vetriner. 145-152pp.

Mahida, U.N. (1986). Pencemaran air dan pemanfaatan limbah industri. CV Rajawali, Jakarta.

Maulidiyanti, Limin, S., \& Siti, H. (2015). Pengaruh pemberian pakan alami Daphnia magna yang diperkaya dengan tepung spirulina terhadap kelangsungan hidup dan pertumbuhan larva ikan komet (Carassius auratus). e-Jurnal Rekayasa dan Teknologi Budidaya Perairan, IV (1), 461-470.

Mubarak, A. S, Tias D. T. R, \& Sulmartiwi, L. (2009). Pemberian Dolomit pada Kultur Daphnia spp. Sistem Daily Feeding pada Populasi Daphnia spp. dan Kestabilan Kualitas Air. Jurnal Ilmu Perikanan dan Kelautan, 1(1): 67-72.
Pangkey, H. (2009). Daphnia dan penggunaannya. Jurnal Perikanan dan Kelautan, V (3), 33-36.

Pennak, R.W. (1989). Coelenterata Fresh - Water Invertebrates of the United States: Protozoa to Molusca. $3^{\text {rd }}$ edition. John Wiley and Sons, Inc, New York. 580p.

Rahayu, D.R.U.S, Carmudi, \& Kusbiyanto. (2012). Pertumbuhan populasi Daphnia sp pada media kombinasi kotoran puyuh dan ayam dengan padat tebar awal berbeda. Prosiding Seminar Nasional: Pengembangan Sumber Daya Pedesaan dan Kearifan Lokal Berkelanjutan II, 46-52.

Wulan. (2014). Analisis Kandungan Limbah Cair Pabrik Tempe. Universitas Diponegoro, Semarang.

Yanuartono, Alfarizi, N., Soedarmanto I., \& Nurman H. (2018). Manure Unggas: Suplemen Pakan Alternatif dan Dampak Terhadap Lingkungan. Jurnal Bioteknologi dan Biosains Indonesia, 5 (2), 241257. 